The American Geographical Society's

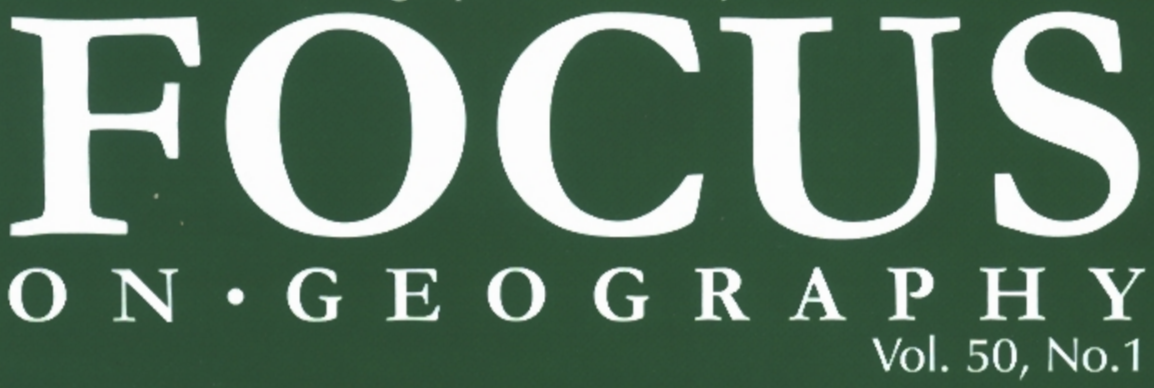

In FOCUS Summer 2007

Jamaican Diaspora in Toronto
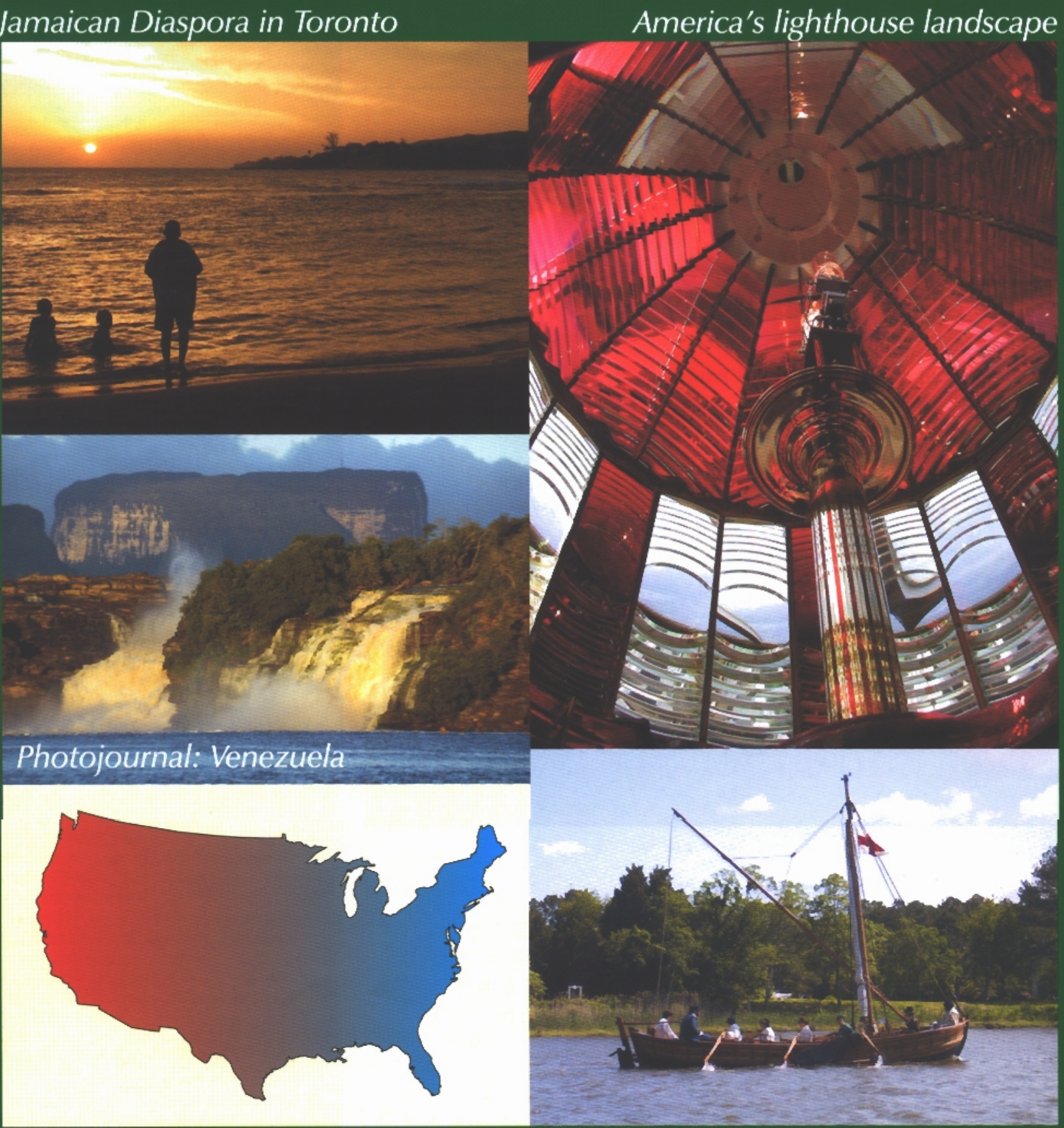

Red America and Blue America

Legacies of Captain John Smith 


\section{Lighthouse Symbolism in the American Landscape}

Few structures built for an utilitarian purpose can evoke such complex human emotions as lighthouses, anachronisms from a bygone system of maritime navigation that are now historic treasures inspiring mystical feelings. The melding of people and environment in the landscape of lighthouses make them key icons in place identity and far more than faddish decor they are symbols of national achievement, dependability under duress, hope, and even religious faith. Some Americans see their lighthouses as equivalent to European castles, structures of permanence worth preservation to tie together multiple generations and provide a focal point for cultural memory (Blake and Smith 2000). Others find personal meaning, with the beacon serving as a metaphor of guidance in their own spiritual quest. These differing perspectives of lighthouses all inspire an affinity for the special places created at the meeting point of water and earth.

Whether it is a soaring tower against a blue sky or a comforting light on the darkest night, lighthouses hold appeal for women and men, young and old. Lighthouse symbolism transcends culture and time as well, as witnessed by three of the world's most famous lighthouses, which blend art with a light guiding ships into harbor: the Colossus of Rhodes (Helios) and the Pharos of Alexandria, both hailed as among the Seven Wonders of the Ancient World and a later sculpture inspired by the Colossus the Statue of Liberty. Symbolism and art were the primary aim in the construction of the Colossus and Lady Liberty, with the lighthouse function integral but secondary, whereas the Pharos of Alexandria was the world's first known lighthouse constructed expressly to cast a beacon. The Pharos was built 2,300 years ago to a height of well over 400 feet (the tallest lighthouse ever), and it stood for 1,500 years until it was destroyed by an earthquake, meeting the same fate as the Colossus of Rhodes. The age, height, and mythical status of the tower results in "pharos" as the root word for lighthouse in several languages and "pharologist" for a person studying lighthouses.

\section{Guiding Lights} metaphors guiding me to the key symbolic traits of lighthouses. My first view of Oregon's Heceta Head Lighthouse from the south, along US Highway 101, has never been matched for its striking composition of the dark green, conifer-draped headland rising one thousand feet above a deep blue
Three scenes stand out in my travels as

sea into a crystalline sky, the white frame keeper's house set high amidst the trees above a sandy beach with foaming breakers, and the sturdy tower impossibly perched above the crags farther out on the headland (Figure 1).

Another eye-catching sight occurred after climbing 175-foot tall Ponce de Leon Inlet Lighthouse in Ponce Inlet, Florida, the state's highest lighthouse, and stepping out onto the narrow cast iron deck of the watch room gallery. The deep shadow of the tower slanted diagonally across the square layout of the light station grounds, a prospect of contrasting patterns and light intensity that was like an abstract lighthouse painting on Earth's canvas

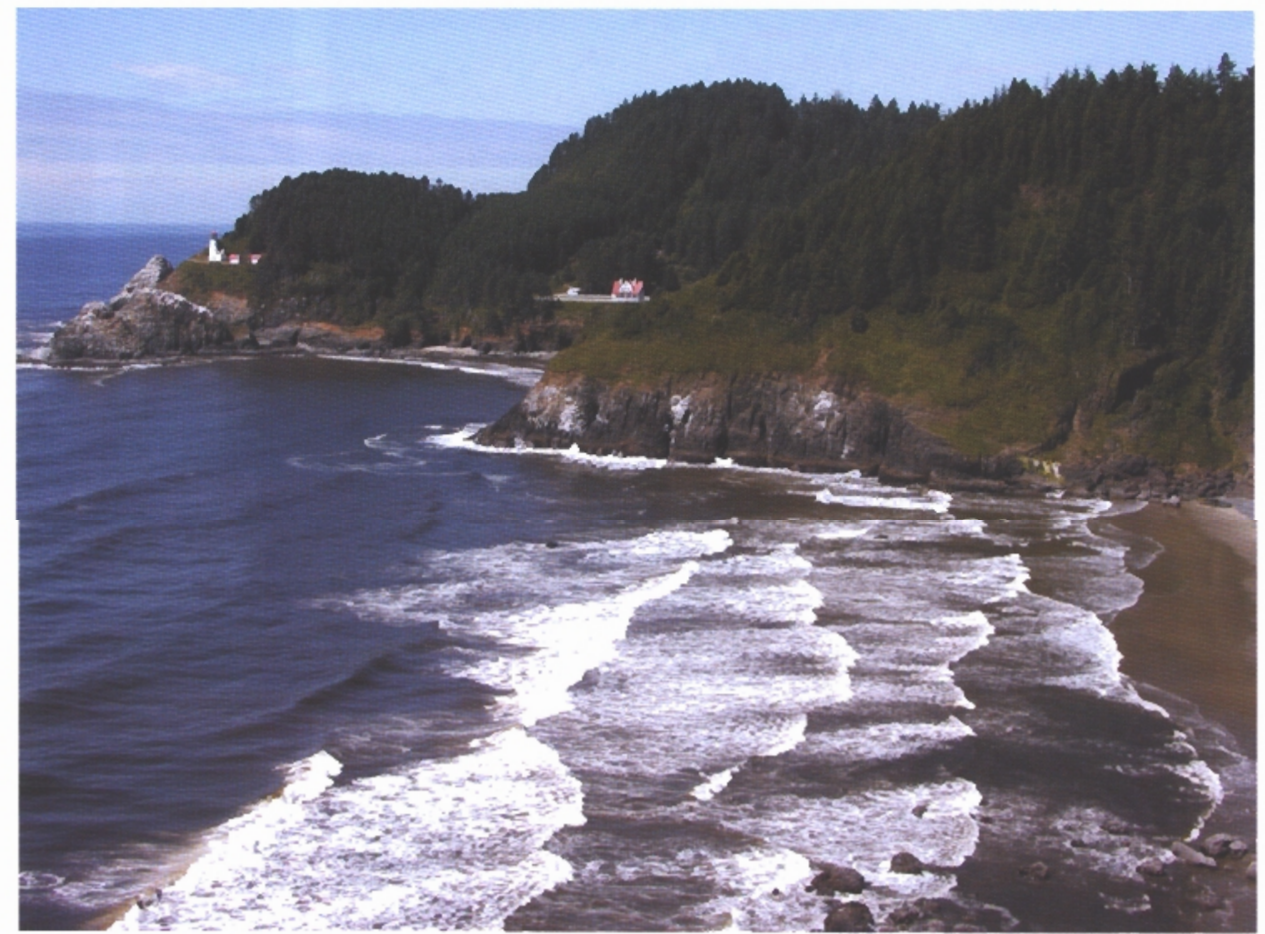

Fig. 1: Often called the most beautiful lighthouse setting in America, Heceta Head Lighthouse and its nearby keeper's quarters grace the tip of the conifer-draped headland along U.S. Highway 101 just north of Florence, Oregon. Photo by the author, July 2001. 
(Figure 2). It was a moment filling my imagination with a sight typically only viewed from the wings of birds.

My third moment of realization about how lighthouse symbolism is communicated in unexpected ways happened when I entered the lighthouse lens building at the Westport Maritime Museum (Westport, Washington) and first saw an illuminated Fresnel lens. It was not just any lens, but a 17-foot-tall, first order behemoth from the Destruction Island Lighthouse, which contains over 1,150 individual hand-ground glass prisms that refract light into a beam that could be seen for 24 miles at sea. The light pouring out from the lens and the organ music piped through the room's speakers made me feel like I was in a cathedral of the Sun God (Figure 3).

The visual, auditory, tactile, and kinetic qualities of these experiences shape my perspective on the main symbolic elements of lighthouses: height, stairwell, lens, topography, architecture, and daymark (lighthouse paint color and pattern). This essay evokes each of these in turn, followed by examples of how lighthouse symbolism is projected on the American landscape with a focus on what within the pantheon of lighthouse symbolism is distinctive at the local, regional, or national scale. I also discuss my nomination of four American lighthouses as symbolically primate within their region, my "first order lighthouses," to borrow the ordinal terminology of lighthouse lens sizes.

In the spirit of D. W. Meinig's (1983) call for geographers to participate in the humanities rather than only borrow from them, my purpose here is to explore connections between lighthouses and human experience, thus this essay is explicitly personal and iconological. Meinig realized that for us to help shape the world, we must first probe deeply into what it means. This may be done by following the oldest tradition of geography, which, according to Carl Sauer (1941), is the art of understanding land and life in creating place personality. Engaging with lighthouses from this perspective, I highlight the character of lighthouses that, in my experience of reading the landscape, kindle the spirit of life. The shape, color, scale, and history of lighthouse settings and structures resonate deeply with visitors and nearby residents, creating a unique aesthetic scene with a meaning that is communicated through media as diverse as postcards and welcome signs.

But, first, what is a lighthouse? It is a structure built to display a maritime beacon as an aid to navigation that marks a known point an important place, such as a headland, shoal, or harbor entrance. The fallacy in that definition, however, is that it qualifies a modern cinderblock structure, such as the one at Cape Meares, Oregon, as a lighthouse, yet no tourist gives the ugly. squat building a second glance compared to the historic cast iron octagonal tower. A

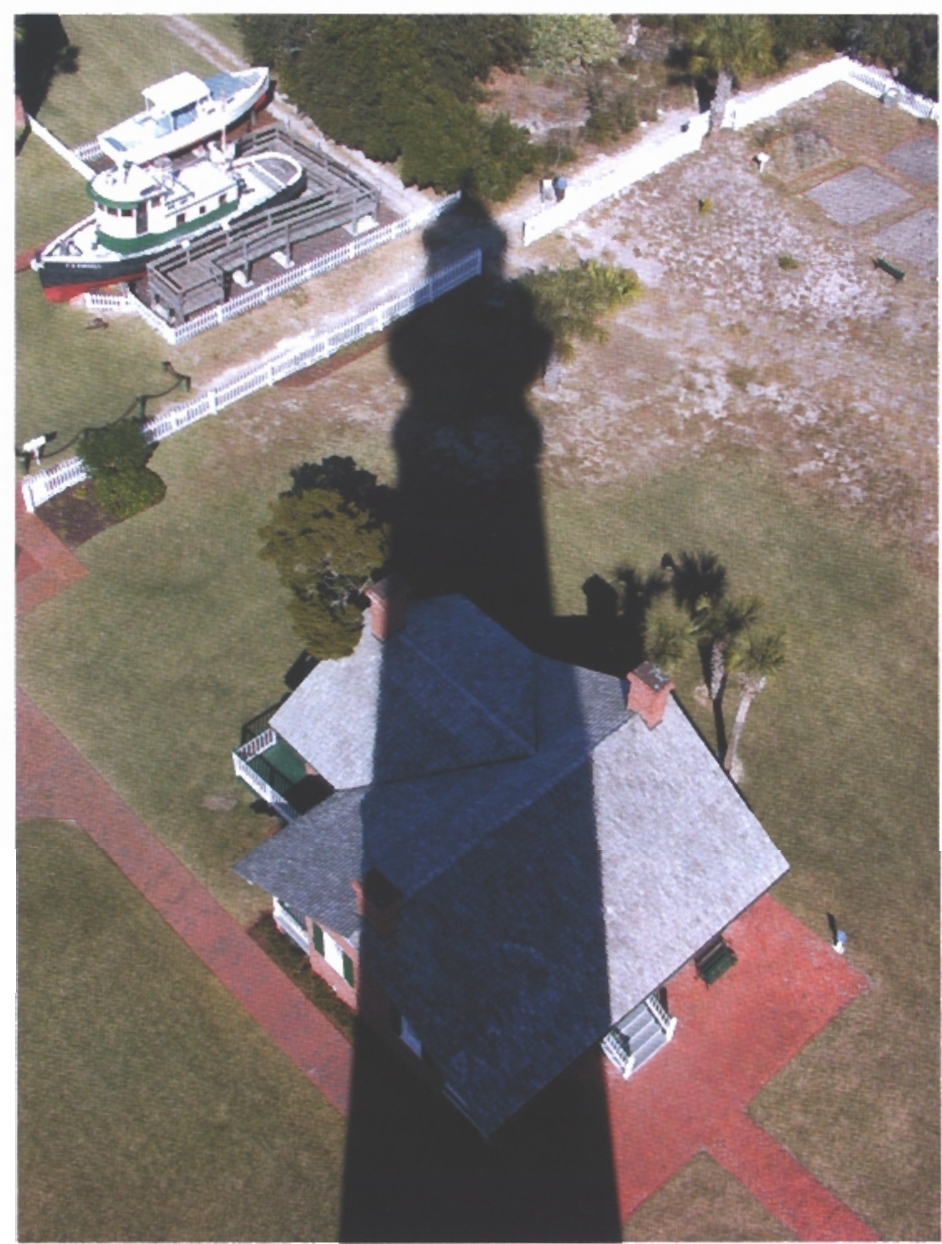

Fig. 2: The afternoon shadow of the 175-foot Ponce de Leon Inlet (Florida) tower is cast across the well-preserved light station grounds. Two hundred and three steps lead to the watch room gallery and its airy views. Photo by the author, January 2004.

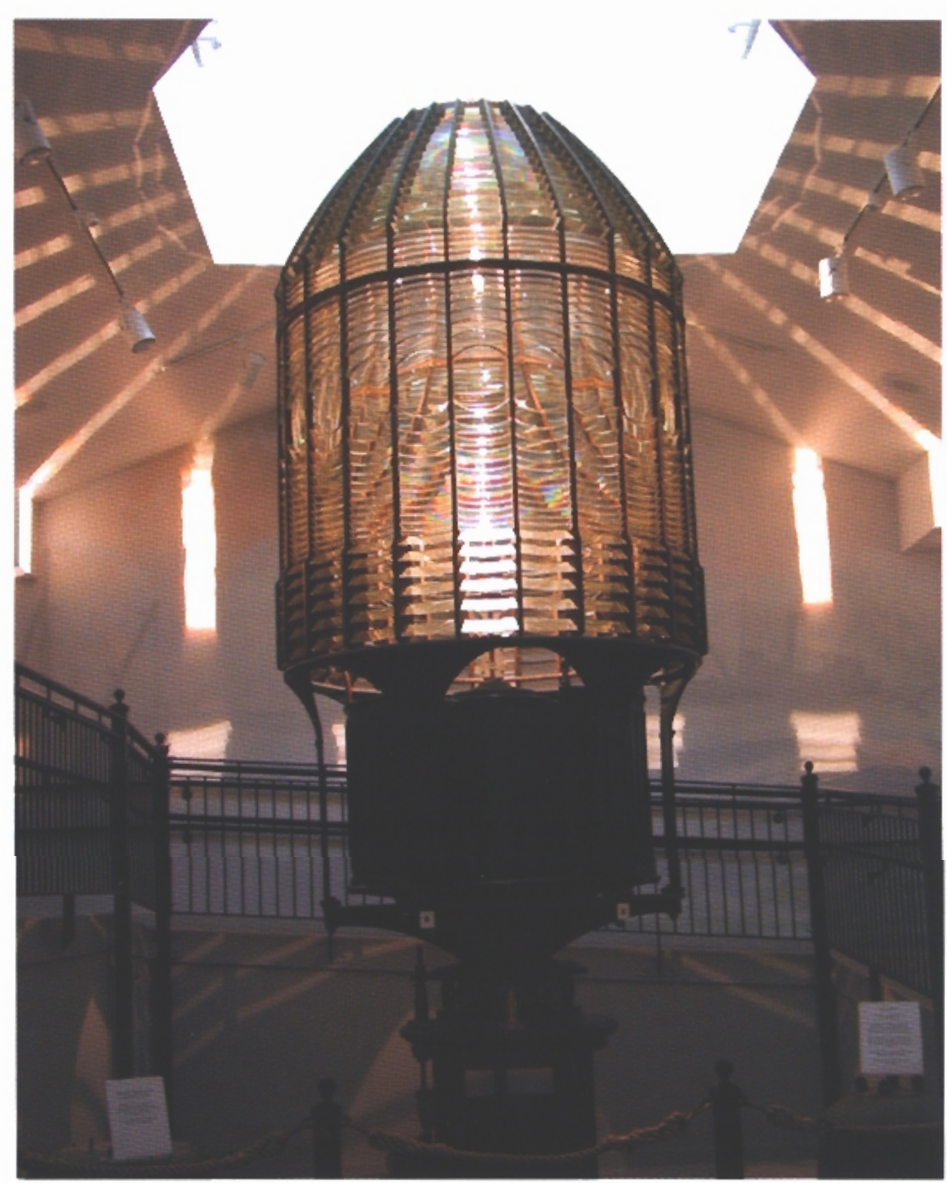

Fig. 3: The first order Fresnel lens from the Destruction Island (Washington) Lighthouse is displayed at the Westport (Washington) Maritime Museum. Including its rotating base, the lens is 17 feet tall and weighs over five tons. The lens is displayed in a separate building, complete with artificial and natural illumination, music, viewing ramps, and interpretive signs. Photo by the author, July 2001. 
cultural dimension is thus critical to defining lighthouses: the structure must have been maintained by a lighthouse keeper who could enter the tower. In ancient times, priests were the lighthouse keepers, because "the union of fire and water, of land and sky, turned a simple fire on the shore into a mythical symbol that only a priest could command" (Guichard and Gast 2002). The symbolism of the keeper is still strong through tales of their heroic rescue of shipwrecked sailors and keeping the flame lit through the worst gales.

Approximately 1,500 lighthouses were constructed in the United States, but no more than about 850 were probably in operation at any one time, most likely around 1910 at the heyday of shipping prior to World War I and before the introduction of the radio beacon in $1921^{1}$. Today, approximately 580 lighthouses remain standing in various states of repair? Seafarers agree that lighthouses are still needed, even with global positioning systems, as reassuring landmarks and in case of shipboard electrical failure (Lighthouse Facts 2006).

Every year a few more lighthouses are lost from what Lighthouse Digest magazine calls its "doomsday list" of threatened light stations (the June 2006 issue tallies 53). In 2005, although Hurricane Katrina obliterated the Chandeleur and New Canal lighthouses in Louisiana and the Ship Island Lighthouse replica in Mississippi, the survival of the Biloxi Lighthouse provides a resolute symbol of strength and permanence for Gulf Coasters. The simple elegance of Biloxi's cast iron tower, also famous for riding out Hurricane Camille in 1969 , is a reminder that hurricane-resistant structures need not be devoid of artistic grace.

\section{Soaring Sentinels}

When it comes to idealized features that contribute to lighthouse symbolism, tower height may reign supreme. Boosterism runs rampant on this score: after Cape Hatteras, North Carolina, the nation's tallest lighthouse at 193 feet, Cape Charles in Virginia, Barnegat in New Jersey and Ponce de Leon Inlet in Florida all claim the second rank ${ }^{3}$. Height can be measured in more than one way, however. Vital to the visible range of the light is the focal plane, the height of the light above sea level. On this score, Old Point Loma, California, built in 1855, ranked first at 462 feet, yet its lofty height also led to a brief life as low-lying fog banks often obscured the view of the light from the water. Consequently, the New Point Loma tower was built close to the beach in 1891

\section{Climbing the Nautilus}

Lighthouse symbolism is also shaped by lighthouse tourism, what I call "lighthousing." Some enthusiasts keep life lists of lighthouses visited, much in the same vein as birders checking off new species. Lighthouse festivals are like a feeding frenzy with the opportunity to see multiple lighthouses in a short time, often including ones typically closed to the public. Some of the better known annual multiple-lighthouse public events include the New Jersey Lighthouse Challenge in October, the Maryland Lighthouse Challenge in September, Long Island Lighthouse Challenge in May, Great Lakes Lighthouse Festival (Alpena, MI) in October, and Door County (WI) Lighthouse Walk in May. While visiting the lighthouse grounds brings smiles to all ages, people bond more to lighthouses they can climb; it is the only way to fully appreciate the history, optics, architecture, and height of the tower, in addition to the smell and feel of the cool, dark interior space.

A tower climb also provides a view of vertiginous artistry. Most towers feature circular stairwells with cast iron treads attached to the tower wall, leaving the center space open for additional light or the

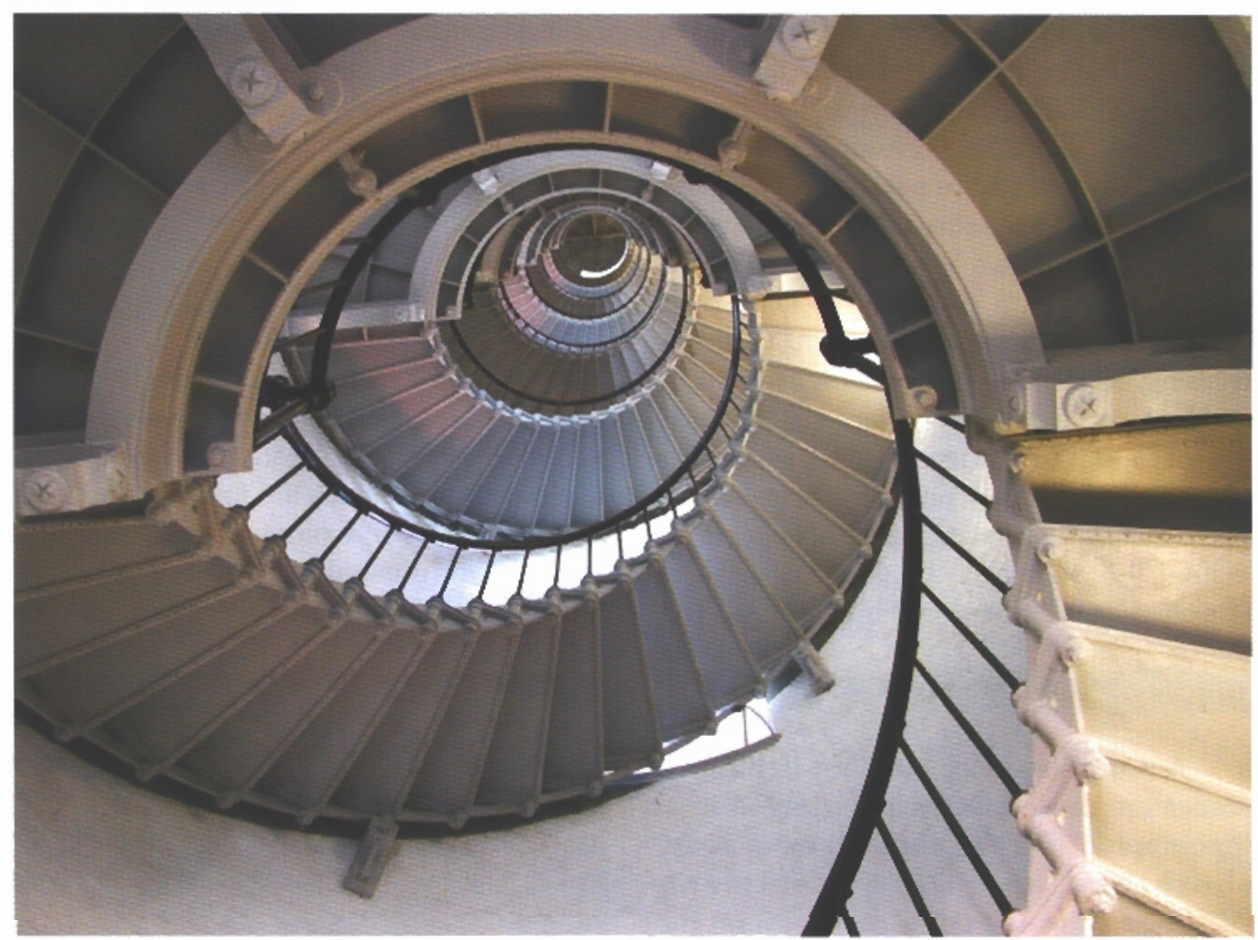

Fig. 4: A view upward in the circular iron stainway inside the Ponce de Leon Inlet Lighthouse is reminiscent of the apparently endless spirals of a nautilus shell. The windows in lighthouse towers are designed to provide light in an otherwise dank, dark environment. Photo by the author, January 2004.

Footnotes:
1 - The lighthouse on Little Brewster Island in Boston Harbor was the first established
in what is today the United States in 1716 . Fighting during the Revolutionary War
destroyed the tower, and a new lighthouse at this location was built in 1783 . The
oldest original operating light tower in the United States is at Sandy Hook, New
Jersey, dating from 1764 .
2 - The United States Lighthouse Society compiles a list of remaining light stations on a
web site maintained by the U.S. Coast Guard: http://www.uscg.mil/hq/g-
cp/history/h_remaininglights.html. This list was last updated in 2002 ; subsequent
hurricanes and fires have destroyed some lighthouses on the list. A light station consists
of a light tower and surrounding grounds with ancillary buildings, such as the keeper's quarters and fuel oil building. Many of these lighthouses are no longer active aids to navigation, with that function transferred to a nearby steel tower. Michigan is the state with the most lighthouses.

3 - Claims of lighthouse height are frequently complicated by uncertain measurements and disagreement as to the starting point for the bottom and top elevations. Ponce de Leon Inlet Lighthouse makes a strong claim to the second highest rank (Crompton and Rhein 2003) with a brick tower reaching 175 feet in height, higher than both Absecon (variously reported as 169 or 171 feet high) and Barnegat (variously reported as 165 or 172 feet high). Cape Charles Light is taller than Ponce de Leon, but as a cast iron skeleton tower, it fails to meet the definition of a lighthouse held by some people. 
operation of the weights driving the clockworks that rotate the lens. In a tall tower, the upward ascent is like a journey inside a nautilus, with a perspective of seemingly endless spirals drawing the climber ever onward into dizzying heights (Figure 4).

\section{Gems of the Night}

The goal of climbing the stairwell is usually to see the lens, but all lenses are not equally alluring. The lenses that infuse the strongest sense of art into a lighthouse are Fresnel lenses, the gems of the night. First produced by French physicist Augustin Fresnel in the early 1820s, Fresnel lenses proved far superior to parabolic mirror systems in concentrating a light (Tag 2004). Fresnel described the lenses according to their size, ranging from the diminutive sixth order up to the massive first order. Some lenses were stationary, others were designed to rotate with bulls-eyes to create a flash, and others were fitted with colored or occluded panels, all in an effort to create the unique "characteristic" or signature for each light. Precisely ground and fitted, Fresnel lens prisms are nearly irreplaceable today, and intact lenses are appraised at millions of dollars. The prize of a Fresnel lens in a museum collection is enough to spawn the lighthouse equivalent of grave robbing, separating a Fresnel lens from its original context. But when a first order Fresnel lens is still in its original tower, it is a viewing opportunity not to be missed, such as the brilliant prismatic effect of looking up inside the red and clear glass lens at Umpqua River, Oregon (Figure 5).

\section{Beacons of Repulsion and Attraction}

Among the most pleasing lighthouse scenes are those that include rugged local topography, like the cliffs above a rocky shore at Cape Disappointment, Washington, or the tall sand dunes on the eastern shore of Lake Michigan at Big Sable. Lighthouse settings are renowned for their ability to incongruously inspire both fear and longing, often depending on the weather. Some beacons are designed to attract ships and guide safe passage to a harbor or shipping lane. Others warn mariners away from dangerous shoals or headlands. This image of a beacon of repulsion harkens back to the difficult tours of duty for lightkeepers in an isolated and unforgiving locale, an image that plays well in the national myth of rugged individualism overcoming harsh environments with an adventurous spirit.

\section{Form and Function}

Reflecting various eras of architectural styles, the availability of materials and skilled labor, regional custom, and local topography, lighthouses feature a spectrum of architectural interest, whether in the design of the tower, keeper's quarters, doorway, or lantern room. Even the pattern of storm panes on a lantern varies from small rectangles forming a birdcage appearance, such as at New York's Selkirk Lighthouse, to larger rectangular, triangular, or diamond shapes. The terminology used to describe the various towers sounds like it comes from a child's erector set: screwpile, skeleton, sparkplug, bottle, cupola, conical, cylindrical, square, pyramidal, hexagonal, octagonal, and integral. Furthermore, to enable travel along piers when storm waves pound over the wall, elevated catwalks connect many Lake Michigan lights to shore. The play of sunlight or fog on the geometric catwalk and pier at Wisconsin's Sturgeon Bay North Pierhead Lighthouse blends form and function in the lighthouse landscape (Figure 6).

\section{Painting Lake Michigan Red}

Daymark refers to the distinctive paint color or pattern that causes the tower to be a valuable guide to navigation in the daytime. Red, white, and black are favorite daymark colors, as is a stripe pattern. Lake Michigan features an unusual preponderance of red lighthouses. The relatively gentle coastal

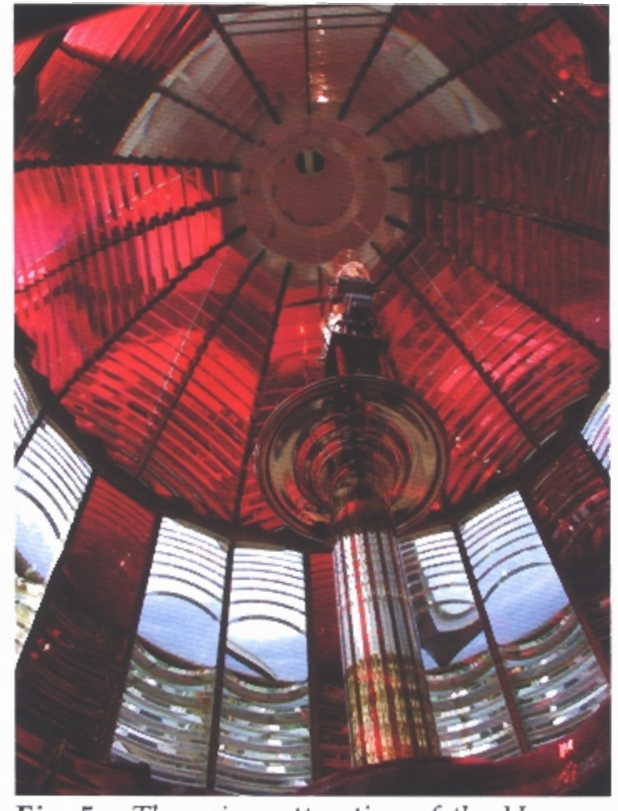

Fig. 5: The prime attraction of the Umpqua River Lighthouse in Winchester Bay, Oregon, is its original, in situ first order Fresnel lens, first placed in operation in 1894. The lens was manufactured by Barbier $\mathcal{E}$ Cie of Paris in 1890. The bulls-eye prisms of clear and red glass produce a characteristic two white flashes and one red flash every fifteen seconds, visible 20 miles out to sea. Photo by author, Sept, 2003.

topography of Lake Michigan compared to Lake Superior, for example, and the beneficial location of Lake Michigan with respect to North American settlement patterns results in its plethora of harbors. Many are protected from storm waves by a pair of piers extending outward. Navigational custom calls for the outermost point on the pier to be lit with a red light

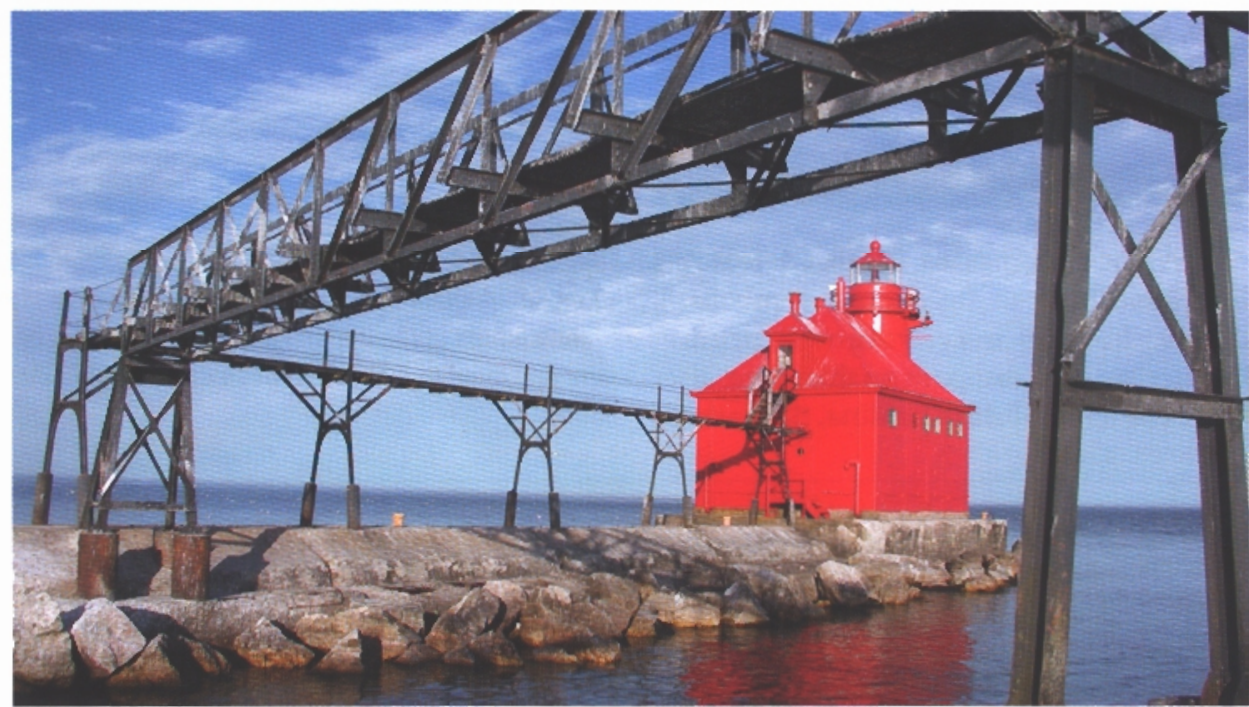

Fig. 6: Typical of the Lake Michigan pier head lighthouses, the Sturgeon Bay (Wisconsin) Ship Canal North Pier Head Lighthouse is painted bright red and is accessed via an elevated catwalk. Photo by the author, July 2003. 
placed on the port or left side of the channel when viewed from a boat exiting the harbor and a green light to starboard. Red is thus the logical choice for the daymark of portside pierhead lights on Lake Michigan. Owing to the better visibility of red than green, especially in fog, red pierhead lighthouses are more numerous than any other color. Their vivid coloration results in a special attachment to them by local residents, perhaps best illustrated by the "Big Red" nickname for the small pier lighthouse in Holland, Michigan. Around the lake, the red lighthouses contrast sharply with the sunny blue waters of summer playgrounds or the wind-whipped winter ice piled against shoals and shorelines.

\section{Lighthouse Symbolism}

How, then, do these lighthouse traits reflect and shape lighthouse symbolism? Multiple factors operate simultaneously. Signage plays a prominent role reflecting the meaning of a light in the identity of a town, such as the icon of the Yaquina Head Lighthouse on the Newport, Oregon, welcome sign with the slogan, "the friendliest," suggesting that lighthouses make for pleasant towns. The closer a town is to a lighthouse, the greater likelihood the lighthouse icon will echo the actual tower rather than appear as a generic tower. In Bandon, Oregon, for example, the Coquille River Lighthouse outshines nearby dramatic sea stacks and golf resorts as a community symbol on dozens of murals and business signs, plus the town logo.

Lighthouse symbolism also occurs through the use of lighthouses in yard ornamentation, a custom I am tempted to call "lightscaping." From birdfeeders to mailboxes to miniature replicas, lighthouses dot the residential and commercial landscape near and far from the nation's coasts. Arizona's Lake Havasu Lighthouse Club has embarked on a surreal lightscaping project with twelve replicas of beacons from throughout North America peppering the shores of the desert reservoir, including West Quoddy Head (Maine), East Quoddy Head (New Brunswick), Table Bluff (California), Boston Harbor (Massachusetts), Robert Manning Memorial (Michigan), Alpena (Michigan), Cape Hatteras (North Carolina), Currituck (North Carolina), Buffalo Main (New York), Split Rock (Minnesota), Sandy Hook (New Jersey), and Vermilion (Ohio). More are on the way.

Lighthouse symbolism has been widely projected in America for at least a century; two examples of lighthouse representations from the early $1900 \mathrm{~s}$ include postcards and cigarette trading cards. Postage stamps and replica sculptures were popular issues in the late 1900 s, a time when lighthouse symbolism also regularly appeared in song and cinema. In the 1995 remake of "Sabrina," a jaded Wall Street businessman named Linus Larrabee, played by Harrison Ford, is wallowing in misery, talking of his loneliness and depression, when his eyes fall upon the Edgartown Harbor Light on Martha's Vineyard and acted out the following script:

Lighthouse. Guy going into the lighthouse. There's a job for you. What must that be like? What kind of guy takes a job keeping a lighthouse?

This scene is a key moment in the transformation of his character from shallow and self-centered to complex and caring, with the lighthouse symbolizing the change from trite to reflective. Another example of lighthouses in film as symbols of hope is "Pearl Harbor" (2001), in which Kate Beckinsale reads love letters from her faraway beau while standing on a lighthouse (Point Vicente, California, though the scene is set in Hawaii). The 1992 film "Forever Young" prominently features the Point Arena Lighthouse (California) as a symbol of love's hope and reunion, with the climactic scenes played out in the sky above and on the grounds of the tower. The release in 2000 of the Nickel Creek song "The Lighthouse's Tale" evoked the ongoing permanence of lighthouses continuing to shine even through harsh weather and human tragedy.

The longstanding cultural significance of American lighthouses is institutionalized in the National Lighthouse Preservation Act of 2000, which provides for the transfer of lighthouses no longer considered essential by the Coast Guard to other government agencies or nongovernmental organizations that will preserve the lighthouses and offer public access. Over 300 light stations will potentially be transferred in the first decade of the act (Wallace 2002). Local lighthouse preservation movements reach back several decades, however, such as the 1961 "save the lighthouse" cause that launched a broader historic preservation movement in downtown Buffalo. The rising tide of lighthouse popularity in the 1990s, culminating in the lighthouse preservation act, likely swelled with the increasing threats to the integrity of lighthouse structures after decades of neglected maintenance due to the Coast Guard's focus on providing a reliable aid to navigation rather than preserving lighthouses. The preservation of lighthouses and lighthouse symbolism may still face some obstacles. Competition for the title to a lighthouse may later result in accusations of failure to live up to the deed restrictions ensuring preservation and access (Harrison 2005). Lighthouses have thus reshaped how Americans view the disposal of surplus public property: no longer solely a decision of economics, function, or the federal bureaucracy, the process must now consider culture and symbolism.

\section{First Order Lighthouses}

Some lights shine brighter than others in the symbolic meeting of lighthouses and landscapes. My "first order lighthouses" are not necessarily the oldest or tallest or brightest, but they are certainly among the most loved. I nominate one lighthouse as a first order lighthouse for each of the four main lighthouse regions in the United States: Southeast, Northeast, Great Lakes, and Pacific. Each is a case study of place identity in the lighthouse landscape.

\section{The Big Barber Pole}

Known locally as "the big barber pole" because of its bold, spiraling black and white stripes, Cape Hatteras has warned sailors away from the Graveyard of the Atlantic shoals since 1870. The lighthouse height, daymark, accessibility, and history contribute to its role as my first order lighthouse of the Southeast. I first became fixated with lighthouses upon seeing the 1972 national parks centennial commemorative postage stamps featuring the lighthouse at Cape Hatteras National Seashore (Figure 7). Two years later, I became one of the hundreds of thousands of annual visitors who climb more than 250 tower steps to the highest point on the Outer Banks. Evidence of the continued significance of the Cape Hatteras Lighthouse as a national symbol came in 1999 when the dynamic barrier island shoreline had encroached close enough to 


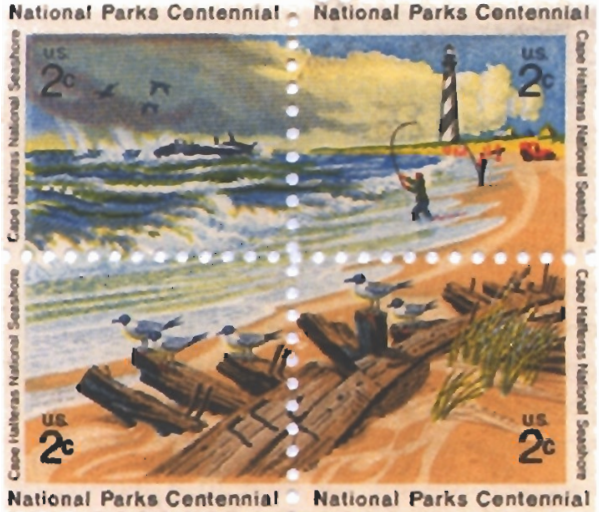

Fig. 7: Commenorating the centennial of the first national park, this 1972 U.S. postage stamp issue features the nation's tallest lighthouse at Cape Hatteras (North Carolina) National Seashore. From the author's collection.

the tower to threaten its stability. A National Park Service study recommended moving the tower, and nightly newscasts throughout the summer portrayed first the controversy over whether the tower should be moved and then the slow, dramatic process of moving the 2,800-ton brick tower over one-half mile to a point of relative safety.

\section{Longfellow's Lighthouse}

In the Northeast region, I choose Portland Head, Maine, as a first order lighthouse, even though Pemaquid Point Lighthouse was the inspiration for the Maine state quarter design. Portland Head's symbolism is enhanced by a rich history dating back to its construction, which was authorized by George Washington in 1787 and completed in 1791. This tower was possibly also the inspiration for Portland native Henry Wadsworth Longfellow's poem "The Lighthouse" and its imagery of tempestuous waves, massive masonry, stately ships, and inextinguishable light (Mariotti 2005) (Figure 8$)^{5}$. Other idealized traits of Portland Head include a focal plane of over a hundred feet, a second order Fresnel lens on display in the keeper's quarters, and an aesthetically pleasing composition and scale; the 80-foot conical stone tower attached to the stately keeper's house seems perfectly proportioned on the rocky headland. Furthermore, its easy accessibility for fall foliage and lighthouse tours contributes to the long lines of buses queued up in adjacent Fort Williams State Park and the status of Portland Head as the most photographed New England light. Portland Head's image has become synonymous with the ideal lighthouse view, as illustrated on the 2003 American Automobile Association advertisement for a tour of Midwestern lighthouses although the photo features Portland Head! Throughout most of the twentieth century, the ideal New England village may have been composed of a steepled church, green common, and white frame houses (Meinig 1979), but late in the century, lighthouses arguably became a more widespread symbol of New England community, reflecting perseverance and hard work, pride in the past, permanence in place, innovation, and intimate ties to powerful forces of nature.
Gibraltar on the Great Lakes

From the Great Lakes region, I nominate Split Rock, Minnesota, as a first order lighthouse. Its apparently impregnable setting on rugged cliffs 168 feet above water is a standard part of Lake Superior iconography (Figure 9). The light station was built in 1910 to guide the giant steel ore freighters. Since this was a roadless area at that time, all materials had to be hoisted up from the lake. With the construction of the North Shore Highway in 1924, Split Rock became one of the most visited lighthouses in the U.S., and now over 150,000 visitors arrive at Split Rock Lighthouse State Park every year. Contributing to Split Rock's premier status among Great Lakes lights is the assemblage of a complete light station, including three keeper's quarters and storage barns, an oil house, and a fog signal building. The grounds are immaculately preserved and uncluttered by recent Coast Guard utilitarian structures. A lighthouse keeper in period uniform welcomes visitors to the tower and lantern room with the original third order bivalve (clamshell-shaped) Fresnel lens still in place, though unlit except during special commemorative events.

\section{Spiritual Encounters in the Night}

My first order lighthouse in the Pacific Coast region is Heceta Head, Oregon, often called the most beautiful lighthouse setting in America. Regional claims refer to it as the nation's most photographed lighthouse,

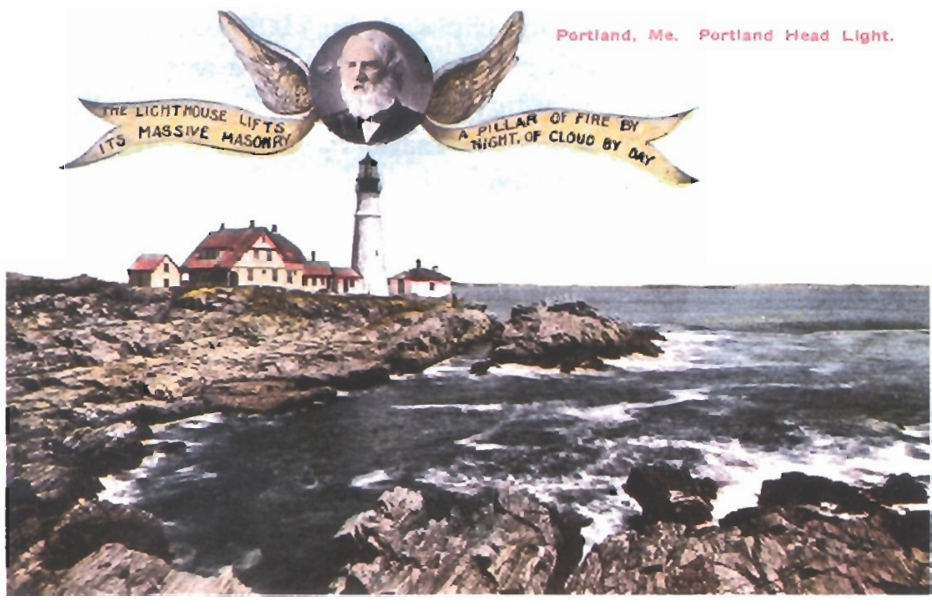

Fig. 8: Thisc. 1911 postcard features Portland Head (Maine) Lighthouse, a photo of Longfellow, and two lines from his poem "The Lighthouse." The poem was first published in 1850 in The Seaside and the Fireside. From the author's collection.

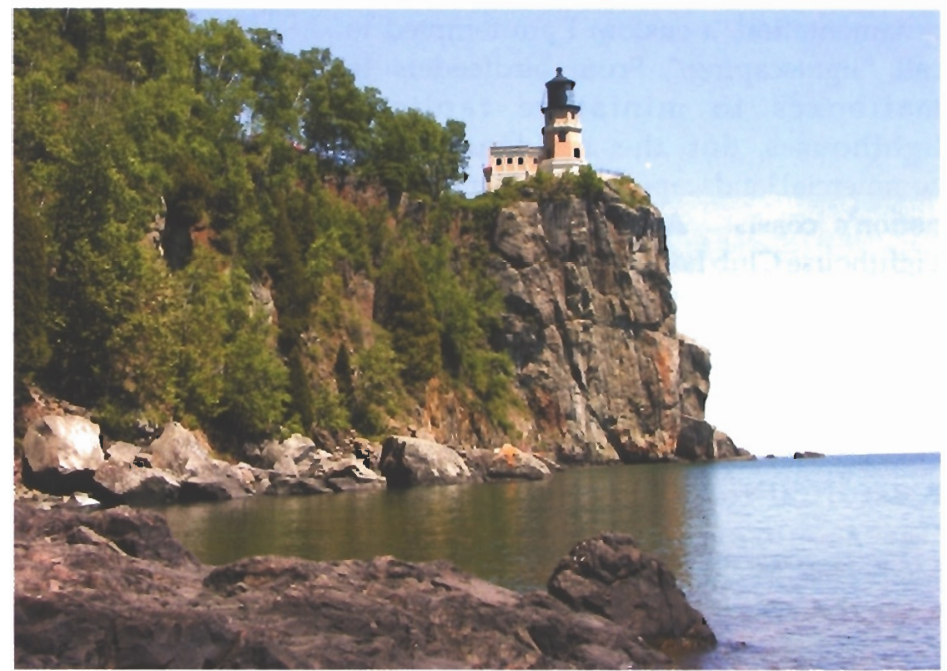

Fig. 9: Split Rock (Minnesota) Lighthouse towers Gibraltar-like above Lake Superior. Photo by the author, June 2002. 
and New Englanders say the same about Portland Head, but coast to coast, I have seen more icons of Cape Hatteras than any other lighthouse. Heceta Head Lighthouse State Park nevertheless has occupied high ground in lighthouse symbolism since 1894 due to its incomparable setting, classic architecture, and magnificent lens, which still shines from 205 feet above the sea. While grandeur best describes the overall Heceta Head landscape, a pilgrimage to the light is defined by intimacy. Inaccessible by car, the conical lighthouse is approached by a winding footpath through a quiet, sheltered forest, making the contrasting roar of the waves and wind at the lighthouse even more dramatic. Like Cape Hatteras and Split Rock, the tower is also open to climbing, but only here is it possible to come within inches of an operational revolving first order Fresnel lens.

Heceta Head also offers the rare opportunity to appreciate the magnificent artistry of the revolving light at night with a stay in the bed and breakfast operated in the Queen Anne-style keeper's residence. The beacon at night is an irresistible siren for guests at the inn, with most walking alone or in pairs by flashlight along the pitch black trail to spend a few minutes or hours in the company of the rotating beams sweeping overhead with precise regularity, lancing boldly across to the cliffs and far over the sea (Figure 10). It is a magical encounter that many visitors describe in near religious terms. Indeed, Christian traditions often incorporate a light guiding the ship of life and a citadel tower guarding against Satan, thus the combination of the tower and light is a powerful symbol (Biedermann 1994).

The night I was there, I climbed the cliff behind the tower, wondering if something mystical would occur when the powerful beam of this singular lens struck me at close range. But nothing transcendent happened. I, instead, was blinded to the point of losing my footing and almost tumbling down through the shrubbery and trees to the base of the tower. As much as at any lighthouse, though, I fully experienced Heceta Head, proof for me that open access to lighthouses is a key to experiencing their geography and identity.

\section{A Ray of Community Hope and Identity}

Lighthouse symbolism is an identity anchor at the local, regional, and national scale. The image of Heceta Head Lighthouse instantly conjures state and regional identity, much as Split Rock does for Minnesota's North Shore, Portland Head for New England, and Cape Hatteras for the Outer Banks and the entire nation. A distinctly American lighthouse landscape exists in the plethora of tall brick towers and the National Lighthouse Preservation Act, which is reminiscent of efforts over a century earlier to enshrine the majestic scenic landscapes of the American West in national parks. As anchors of local place identity, lighthouses have greater potential to be the primary focus in smaller towns compared to large cities, where lighthouses are often only part of the fleet of identity markers. But no matter what the geographic context, the lighthouse landscape conjures deep meanings tied to nostalgia, permanence, faith, transcendence, and the value of personal connection to place in an increasingly globalized world.

\section{References}

Biedermann, Hans, 1994. Dictionary of Symbolism: Cultural Icons and the Meanings behind Them. New York: Meridian.

Blake, Kevin S., and Jeffrey S. Smith. 2000. Pueblo Mission Churches as Symbols of Permanence and Identity. Geographical Review 90(3): 359-380.

Crompton, Samuel Willard, and Michael J.
Rhein. 2003. The Ultimate Book of Lighthouses. San Diego: Thunder Bay Press.

Guichard, Jean, and René Gast. 2002. Lighthouses of France: The Monuments and Their Keepers. Paris: Flammarion.

Harrison, Tim. 2005. Wickie's Wisdom: More Insanity at Currituck Lighthouse. Lighthouse Digest, April: 46.

Lighthouse Facts. 2006. San Francisco: United States Lighthouse Society. [http://www.uslhs.org/resources_materi als.php].

Mariotti, Annamaria Lilla. 2005. The World's Greatest Lighthouses. Vercelli, Italy: White Star.

Meinig, D.W., ed. 1979. Symbolic Landscapes: Some Idealizations of American Communities. In The Interpretation of Ordinary Landscapes: Geographical Essays, 164-192. New York: Oxford University Press.

Meinig, D.W. 1983. Geography as an Art. Transactions of the Institute of British Geographers 8(3): 314-328.

Sauer, Carl.O. 1941. The Personality of Mexico. Geographical Review 31(3):353-364.

Tag, Thomas A. 2004. Who Invented the Fresnel Lens? The Keeper's Log 20(3):18-24.

Wallace, Kathyrn. 2002. Own a Part of Our History. Parade Magazine, 29September: 4-5. Zelinsky, Wilbur. 1988. Where Every Town is Above Average: Welcoming Signs along America's Highways. Landscape 30(1):1-10.

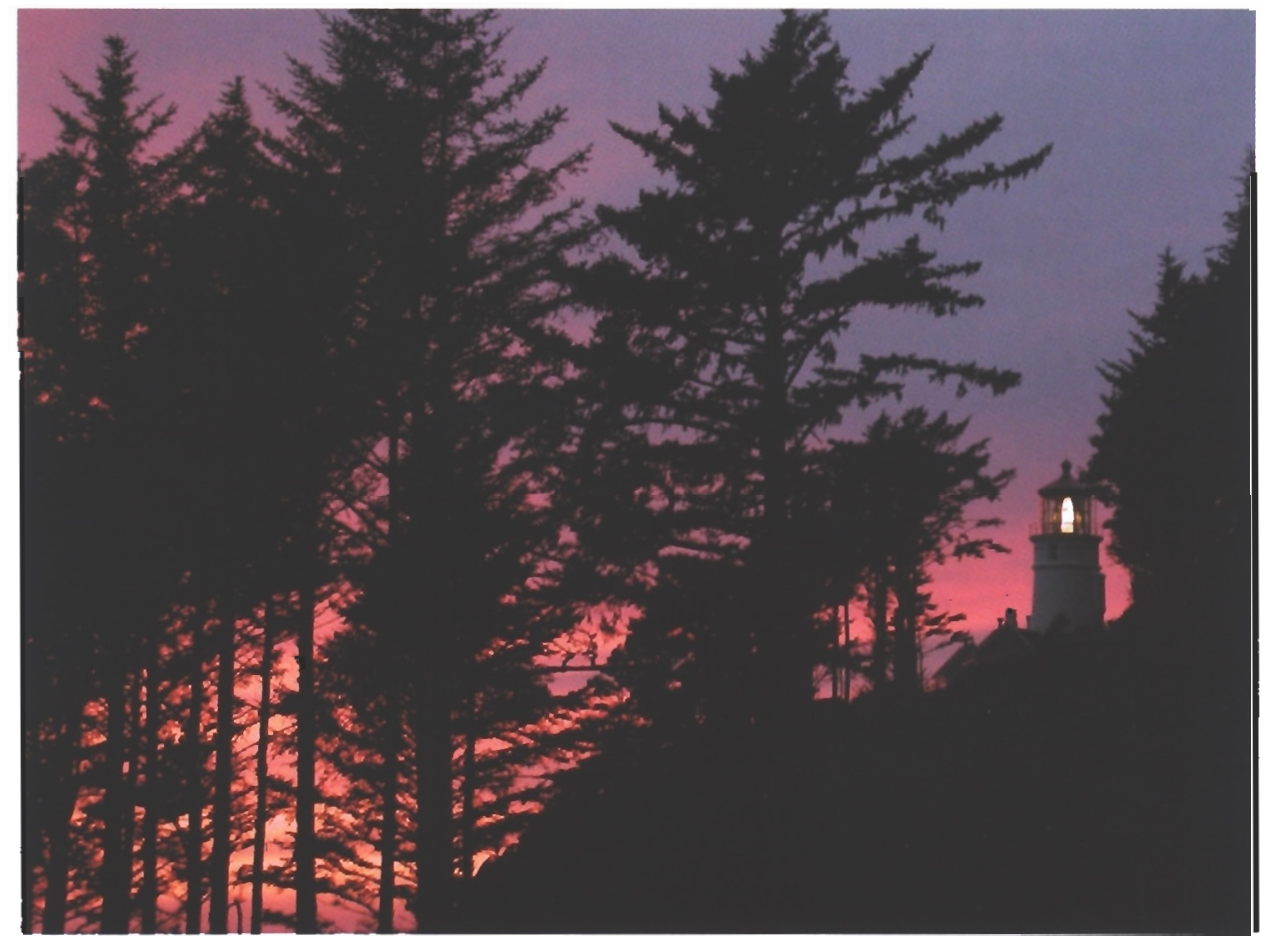

Fig. 10: Heceta Head (Oregon) Lighthouse at sunset. Photo by the author, September 2003.

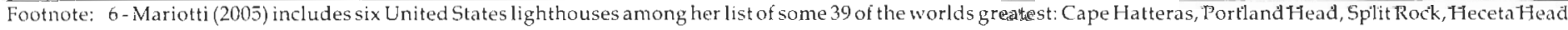
Bodie Island, and the two at Point Loma. 